El aislamiento y la identificación del virus del herpes en toninas (Tursiops truncatus) de la Laguna de Términos, Campeche, México

\title{
Isolation and Identification of Herpesvirus in the Bottlenose Dolphins (Tursiops truncatus) of Terminos Lagoon, Campeche, Mexico
}

\author{
E. G. Valdivia-Lara ${ }^{1}$, A. Delgado-Estrella ${ }^{4 *}$, J. I. Ángeles-Solís ${ }^{1}$, E. N. Ortuño de la $\mathrm{O}^{1}$, S. González-Gallardo ${ }^{2}$, G .E. \\ Lara-Reyes $^{3}$, C. Cuenca-Verde ${ }^{1}$ y G. Valdivia-Anda ${ }^{1}$
}

\begin{abstract}
1 Unidad de Investigación Multidisciplinaria, Facultad de Estudios Superiores Cuautitlán, Universidad Nacional Autónoma de México. Km 2.5 Carretera Cuautitlán Teoloyucan S/N, San Sebastián Xhala, 54714, Cuautitlán Izcalli Edo. De México,. E-mail: guillermo897@ hotmail.com (EGVL), labdivet@hotmail.com (JIAS), audeladesfrontieres_love@hotmail.com (ENODLO), ccuencaverde@hotmail. com (CCV) y valdivag@gmail.com (GVA)

2Unidad de Microscopía Electrónica, Facultad de Estudios Superiores Cuautitlán, Universidad Nacional Autónoma de México. Km 2.5 Carretera Cuautitlán Teoloyucan S/N, San Sebastián Xhala, 54714, Cuautitlán Izcalli Edo. De México. E-mail:(SGG)

${ }^{3}$ Especialidades en Diagnóstico SA de CV Laboratorio DIVeT ${ }^{\oplus}$. Cuautitlán de R. Rubio, Estado de México. Km 2.5 Carretera Cuautitlán Teoloyucan S/N, San Sebastián Xhala, Cuautitlán Izcalli Edo. De México, C.P. 54714. E-mail: labdivet@hotmail.com (GELR)

4* Facultad de Ciencias Naturales, UNACAR, Calle 56 № 4, Esq. Av. Concordia, Col. Benito Juárez, Ciudad del Carmen, 24180. Campeche, México. E-mail: delgadoestrella@gmail.com (ADE)

${ }^{*}$ Corresponding author
\end{abstract}

Introduction: Alphaherpesviruses have been associated with fatal systemic infections in several cetartiodactyla species. The main goal in this paper is to identify microorganisms in wild bottlenose dolphin samples were taken from animals in Campeche, Mexico.

Methods: Eight free-living bottlenose dolphins (Tursiops truncatus) from the Terminos Lagoon, Mexico, were captured, sampled and released. The animals were sampled for their blood, blow hole secretion, vaginal or prepuce discharge and skin. From the exudates, the cytology was examined, and cell inoculation was performed using bovine kidney cells (MDBK), African green monkey kidney cells (VERO), canine kidney cells (MDCK) and porcine kidney cells (PK15).

Results: After observing the cytopathic effects, the isolates were replicated in the same cell line at least three times. Three isolates were obtained that had a cytolytic effect at $48-72 \mathrm{hr}$. A previously described nested PCR targeting highly conserved regions of the herpesvirus DNA polymerase was performed, as well as transmission electron microscopy (TEM) and immunofluorescence on the infected MDBK cells.

Discussion and conclusions: The animals from which the isolates were obtained were clinically healthy at the time of their capture, and it is likely that these animals act as carriers or reservoirs of the virus.

Key words: Bottlenose dolphins, Herpesvirus, Mexico, Terminos lagoon, wild dolphins. 


\section{Introduction}

Most investigated vertebrate species have at least one, and usually several, endemic herpesvirus. More than 200 herpesvirus species have been identified to date (Maness et al. 2011). When investigating the lineage of herpesvirus, many major subdivisions mirror the phylogenetic branching order of its hosts; thus, the herpesvirus appears to have co-diverged with its hosts and tends to be host-specific (Maness et al. 2011). Given the approximately 5,500 different species of mammals, it can be expected that the number of herpesviruses that exist in nature well exceeds the 200 species that have been identified thus far (Maness et al. 2011). All of the herpesviruses fall within the newly established taxonomic order Herpesvirales, which consists of three families: Herpesviridae (which includes the herpesviruses of mammals, reptiles, and birds), Alloherpesviridae (which includes the herpesviruses of fish and amphibians), and Malacoherpesviridae (bivalve herpesviruses (Changming et al. 2015)). Additionally, the family Herpesviridae contains three subfamilies: Alphaherpesvirinae, Betaherpesvirinae, and Gammaherpesvirinae (Davison 2010). Electron microscopy (EM) and serum neutralization, as well as analyses of other herpesvirus characteristics, were used to identify the alphaherpesvirus in lung and liver isolates (Goldstein et al. 2004). The presence of herpesviruses in cetaceans (the group of animals consisting of all of the porpoises, dolphins, and whales) has been recognized since the late 1980's using electron microscopy (EM) reports of herpesvirus-like particles in skin biopsies from beluga whales (Delphinapterus leucas, Martineau et al. 1988). Few cases of herpesvirus infection have been reported in cetaceans. Alphaherpesviruses have been associated with fatal systemic infections in Bottlenose dolphins (Tursiops truncatus), in a Cuvier's beaked whale (Ziphius cavirostris), and in cutaneous lesions in Bottlenose dolphins (Blanchard et al. 2001). Gammaherpesviruses have been identified in mucosal lesions in Bottlenose dolphins, Risso's dolphins (Grampus griseus), dwarf sperm whales (Kogiasima) and Blainville's beaked whales (Mesoplodon densirostris; Smolarek et al. 2006; Bossart 2007; Van Elk et al. 2009). In addition, nonpurulent encephalitis associated with herpesvirus infection has been described in a harbour porpoise (Phocoena phocoena). In the first report of herpesvirus infection in Mediterranean Sea cetaceans, eight different Herpesvirus sequences were found in five of eight Striped dolphins (Stenella coeruleoalba) that were also infected with Morbillivirus(Soto et al. 2011). In these dolphins, no lesions were found that could be attributed to herpesvirus infection, and the pathogenic contribution of these herpesviruses remains unclear.

Herpesviruses (HV) have also been associated with encephalitis in a harbor porpoise (Phocoena phocoena) and with skin lesions of dusky dolphins (Lagenorhynchus obscurus) corroborated by EM (Soto et al. 2011). In addition to EM, immunoperoxidase staining (Soto et al. 2011), serum neutralization and enzyme-labeled immunosorbent assays have been used as indicators for the presence of herpesviruses in cetaceans (Van Elk et al. 2009). In this report, we document the presence of herpesvirus in free-ranging dolphins from Mexico in order to obtain information about the health status in this population in the southern Gulf of Mexico support future stranding events causes.

\section{Material and Methods}

Bottlenose dolphins were caught from and sampled in the Terminos lagoon, Campeche, Mexico, in the Southern Gulf of Mexico ( $18^{\circ} 23^{\prime}-18^{\circ} 52^{\prime}$ latitude N and $-91^{\circ} 10^{\prime}$ to $-91^{\circ} 52^{\prime}$ longitude W) under the capturing license SGPA/DGVS 09924/10 SEMARNAT, following at all times the guidelines for the use and care of experimental animals, and NOM 062, with each procedure being supervised by a veterinarian. The blood samples were collected from the caudal vein using a Vacutainer ${ }^{\mathrm{TM}}$ system, exudates samples (vaginal, preputial or blowhole) were collected using sterile swabs, and the skin samples were collected using a needle Acu-Punch Kit RM (Acuderm ${ }^{\mathrm{TM}}$ ). 
Six blowholes and three vaginal and four preputial discharges samples were collected for this study. Samples of viral isolates were frozen in liquid nitrogen and thawed at $37{ }^{\circ} \mathrm{C}$, repeating this procedure five times, and were then filtered through $0.2 \mu \mathrm{m}$ Millipore ${ }^{\mathrm{TM}}$ membranes. A 0.5$\mathrm{ml}$ aliquot was inoculated directly into 12-well microplates (NUNC'M $)$ containing cells at $70 \%$ confluence in MEM medium with 3 to $5 \%$ newborn calf serum depending on the cell line. The plates were incubated in a $\mathrm{CO}_{2}$ atmosphere for five days and frozen and thawed 3 times, after which $1 \mathrm{ml}$ was used to infect another cell culture flask; this step was repeated 3 times. The cells showed cytopathic and cytolytic effects.

The following immortalized cell lines were used: Madine-Darby Canine Kidney (MDCK), Bovine Kidney (MDBK) and African green monkey kidney (Vero). All of the immortalized cell lines were obtained from the American Type Culture Collection.

For the immunofluorescence assay, 12 -well NUNC plates were prepared with a coverslip in the bottom, cells were grown to $70 \%$ confluence, and the supernatants of the infected cell cultures were used to infect the cells on the coverslips, which were incubated for 48 - $72 \mathrm{hr}$. The coverslips were removed and fixed in pure acetone for 10 minutes at room temperature. The slides were stained with VMRD ${ }^{\text {TM }}$ Canine Herpesvirus direct FA conjugate according to the manufacturer's recommendations. Other slides were simultaneously stained using the Diff-Quick Stain Kit (Fisher Scientific ${ }^{\text {TM}}$ ).

Herpesvirus DNA was amplified using published degenerate primers designed to target a region of the DNA polymerase gene of herpesviruses that corresponds to highly conserved amino acid motifs (Smolarek et al. 2006). These primers direct the amplification of DNA polymerase gene fragments that are 215 to $235 \mathrm{bp}$ in length for most herpesviruses and $315 \mathrm{bp}$ in length for cytomegaloviruses. A nested PCR assay was performed using two forward and one reverse primer in the first reaction and one forward and one reverse primer in the second reaction. The primer sequences for the first reaction were DFA-5'- GAY TTY GCI AGY YTI TAY CC -3' (forward), ILK-5'- TCC TGG ACA AGC AGC ARI YSG CIM TIA A -3' (forward), KG1-5'- GTC TTG CTC ACC AGI TCI ACI CCY TT - $3^{\prime}$ (reverse). Primers for the second reaction were: TGV-5'- TGT AAC TCG GTG TAY GGI TTY ACI GGI GT -3'(forward), and IYG-5'- CAC AGA GTC CGT RTC ICC RTA IAT -3' (reverse). The total DNA that was extracted from the cell monolayers of the Madine-Darby canine kidney (MDCK) cultures that were infected with canine herpesvirus (CHV) was used as a positive template for the PCR. From the second PCR, $14 \mu \mathrm{l}$ were resolved by horizontal gel electrophoresis in a $1 \%$ agarose gel containing ethidium bromide $(0.5 \mathrm{ug} / \mathrm{ml})$, and the DNA fragments were visualized by UV light trans-illumination.

For electron microscopy, the virus culture samples were fixed with Karnofsky, and a drop was placed on two grids (Sigma Aldrich $62 \mu \mathrm{m}$, copper) for 20 minutes. Then, a drop of distilled water and a drop of $1 \%$ phosphotungstic acid (AFT), pH 7.2, were added for one minute, and the excess dye was removed with filter paper.

The samples were dried at room temperature and were observed and photographed on a transmission electron microscope (JEOL ${ }^{\mathrm{TM}}$ JEM 100S). We used a microparticle size standard based on a monodisperse polystyrene (Sigma Aldrich, Fluka) standard particle size of $2 \mu \mathrm{m}$ as a reference for describing the structures that were observed in the samples. Several measurements at the same amplification were performed, and the average was calculated.

\section{Results}

Of all six blowhole, three vaginal and four preputial secretion discharges samples in this study, we were able to isolate viruses compatible with herpesvirus in three samples (two respiratory and one vaginal discharge). These viruses showed a strong cytolytic effect on the MDBK cells and 
showed no effect on the other cell lines. The effect involved syncytia formation, the presence of inclusion bodies in the cells and cell lysis (Figure 1). All of the infected cell cultures showed strong fluorescence when stained with Canine Herpesvirus direct FA Conjugate (Figure 2).

Transmission electron microscopy revealed the presence of herpesvirus-like encapsidated particles. The average of the measurements was $92 \mathrm{~nm}$ for the virion and $196 \mathrm{~nm}$ for the complete virus with envelope (Figure 3), as previously reported for other dolphins herpesviruses (Rehtanz et al. 2012).

Figure 1. Infected MDBK cells at $48 \mathrm{hr}(\mathrm{A})$ and at $72 \mathrm{hr}$ (B). Cytopathic effects on the cells are seen (A), including syncytia formation (B). Picture A is 100x and picture B is 400x using an inverted microscope. No cytopathic effects were observed on the cells of the negative control. Other cytopathic effects were characterized by morphological changes, including cell rounding, swelling, and detachment.
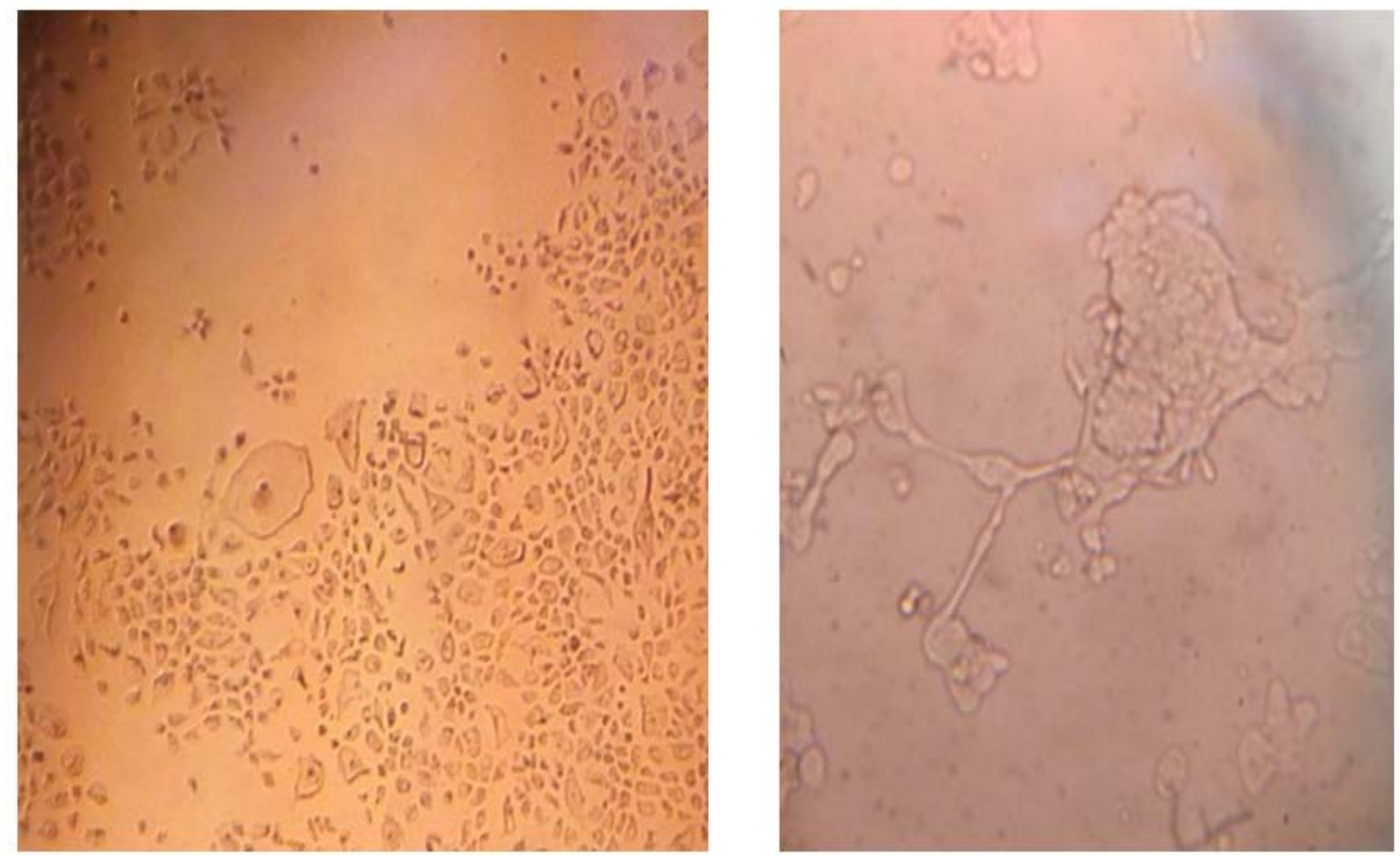

When the PCR was performed using the whole DNA of the samples, amplification was not achieved. Nevertheless, the PCR that was performed using the DNA of isolates resulted in an amplification of $240 \mathrm{bp}$ (Figure 3). The MDBK cells showed high permissibility for the development of the virus from the dolphins, possibly due to the phylogenetic association between dolphins and cattle; the observed effect corresponds to that described for alphaherpesviruses. Cytopathic characteristics,such as viral intranuclear inclusion bodies, syncytia formation and rapid cytolytic effects ( 3 - 5 days), were described for this group.

The immunologic cross-reactivity between the presumed isolated dolphin herpesvirus and the Canine Herpesvirus Direct FA conjugate suggests that the isolated virus is most likely an alphaherpesvirus.

\section{Discussion}

The capacity of herpesviruses to cause disease in cetaceans is unclear and may show variations depending on the conditions of different individuals and species. In a series of 128 samples of skin and mucosal lesions from 12 different cetacean species, as many as 11 different herpesvirus sequences were amplified (nine from 32 mucosal lesions and two from a total of 88 skin lesions), 
Figure 2. Canine Herpesvirus Direct FA, conjugated over infected MDBK cells at $48 \mathrm{hr}$. 400x. Respiratory sample 1 (a) and sample 8 (b) and (c, d) sample 15 vaginal discharges.
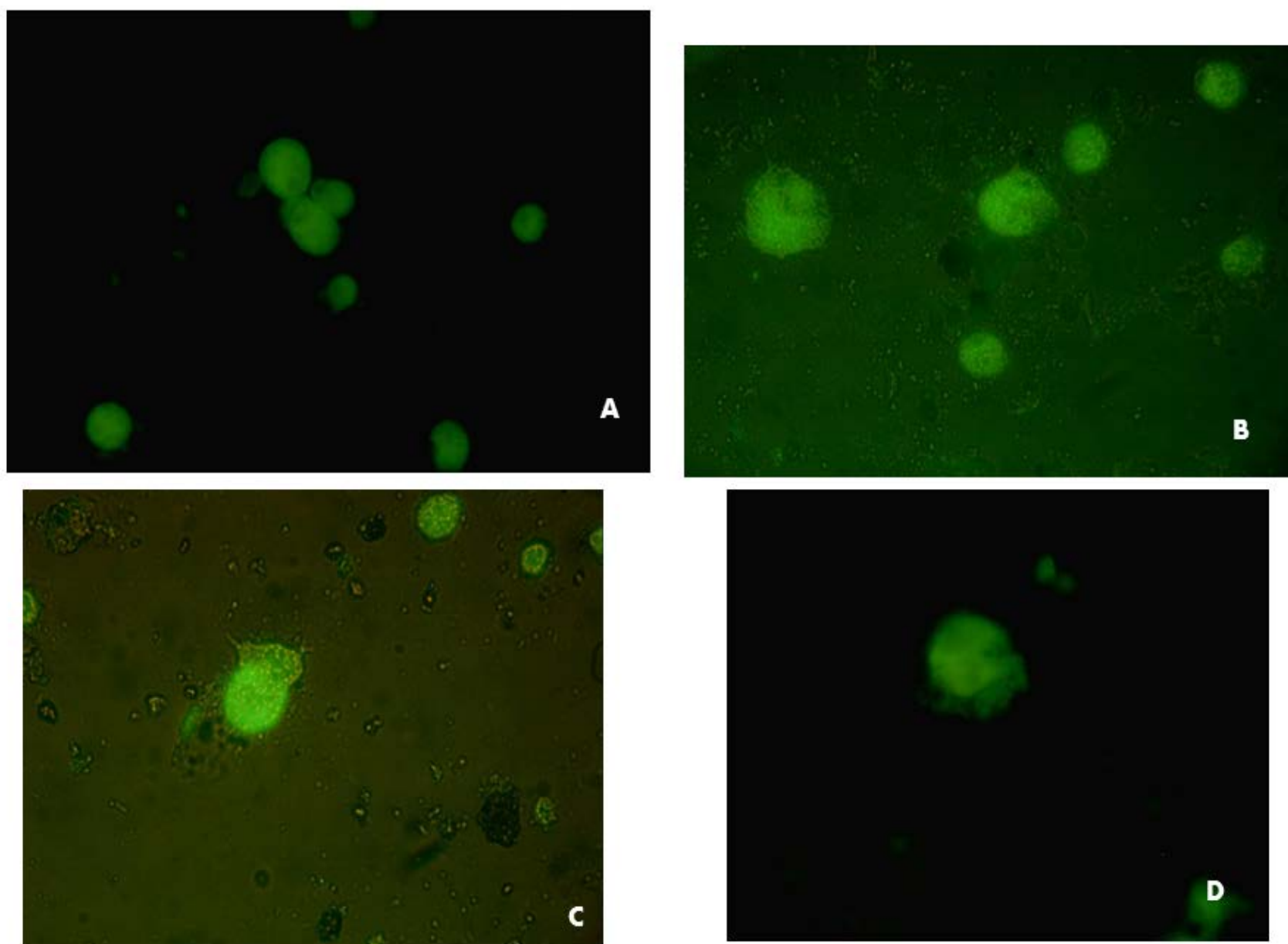

showing an apparently high association of herpesvirus infection with mucosal and skin lesions (Smolarek et al. 2006). However, systemic disease or internal lesions attributable to herpesvirus have been described only sporadically in cetaceans (Blanchard et al. 2001), one Cuvier's beaked whale and harbour porpoise. One disseminated herpesvirus infection was observed in two bottlenose dolphins with necrotizing lesions and eosinophilic intranuclear inclusion bodies in multiple organs (Van Elk et al. 2009). Previous studies have associated the presence of herpesvirus in the skin lesions of fatal systemic diseases in Atlantic bottlenose dolphins (Smolarek et al. 2006).

In cetaceans, the exhaled blowhole sputum can often be diagnostically valuable, as the blowhole possesses wide-bore airways through which the exchange of approximately $80 \%$ of the lung volume occurs in one breath (Varela et al. 2007). In this work, five samples (2/6 blowhole, 2/3 vaginal and $1 / 4$ preputial discharges) were observed, with a greater number of lymphocytes and plasmacells than normal (more than five per high-power field) but no evidence of inclusion bodies (results not shown). Chronic inflammation is typically represented by the presence of lymphocytes (small and large lymphocytes as well as plasma cells) and macrophages (Varela et al. 2007). The lymphocytes possibly belong to T cells, as has been described for other species (Patela et al. 2012). Despite several passes made in the different cell lines, the isolated virus was only able to produce cytopathic effects on the MDBK cells, different from the behavior of phocid gammaherpesviruses, which have been observed in different mammalian cell lines (Byron et al. 2007).

We could not subject to electron microscopy the exudate samples. However, herpesvirus particles were detected from the viral culture; while the amount of viral particles was high, whereas 
in electron microscopy there must be a minimum of $10^{6}-10^{8}$ virus particles $/ \mathrm{ml}$ in a sample to allow for detection (Curry et al. 2006).

We used the microscopic characteristics of herpesviruses for identification (Davison 2010). The electron microscope images showed a capsid structure that consists of a DNA core surrounded by an icosahedral (20-faceted) capsid consisting of 12 and 150 capsomeres. The capsid is embedded in a proteinaceous matrix called the tegument, which in turn is invested in a glycoproteincontaining lipid envelope.

Herpesviruses are more difficult to detect than other viruses in the tissues of marine animals, especially when the viral load is low and the viral type is not yet known. The viral load can be so low that proving the virus's presence may be impossible (Rehtanz et al. 2012). Thus, negative PCR results indicate a lower viral load in the samples associated with the presence of a greater proportion of lymphocytes in the cytology. It has been suggested that the presence of herpesviruses in the cervical secretions could even constitute a prognostic factor for cervical pathology in these dolphins or the establishment of a chronic viral infection. In this sense, two events are fundamental to the establishment of a chronic viral infection: first, the virus must evade sterilizing immunity (the complete elimination of a virus) and second, the immune system must adjust to the continuous presence of viral antigen-driven inflammatory responses in order to limit the viral replication to an acceptable level without untoward damage to permanently infected tissues. If the immune system cannot eliminate the virus, unrestrained immune attack on the virus antigen-bearing cells causes immunopathology. Thus, the down regulation of inflammation during chronic viral infections can result in decreased tissue damage, at least for noncytopathic viruses (Herbert et al. 2009). Moreover, it is rare that herpesvirus PCR sequences

Figure 3. Gel electrophoresis of herpesvirus nested PCR products; MWM: Molecular Weight Marker, lane 1- positive control CHV-1, lane 2- 001 (respiratory secretion), lane 3-008 (respiratory secretion), lane 4- 015 (vaginal discharge), lane 5- negative control.

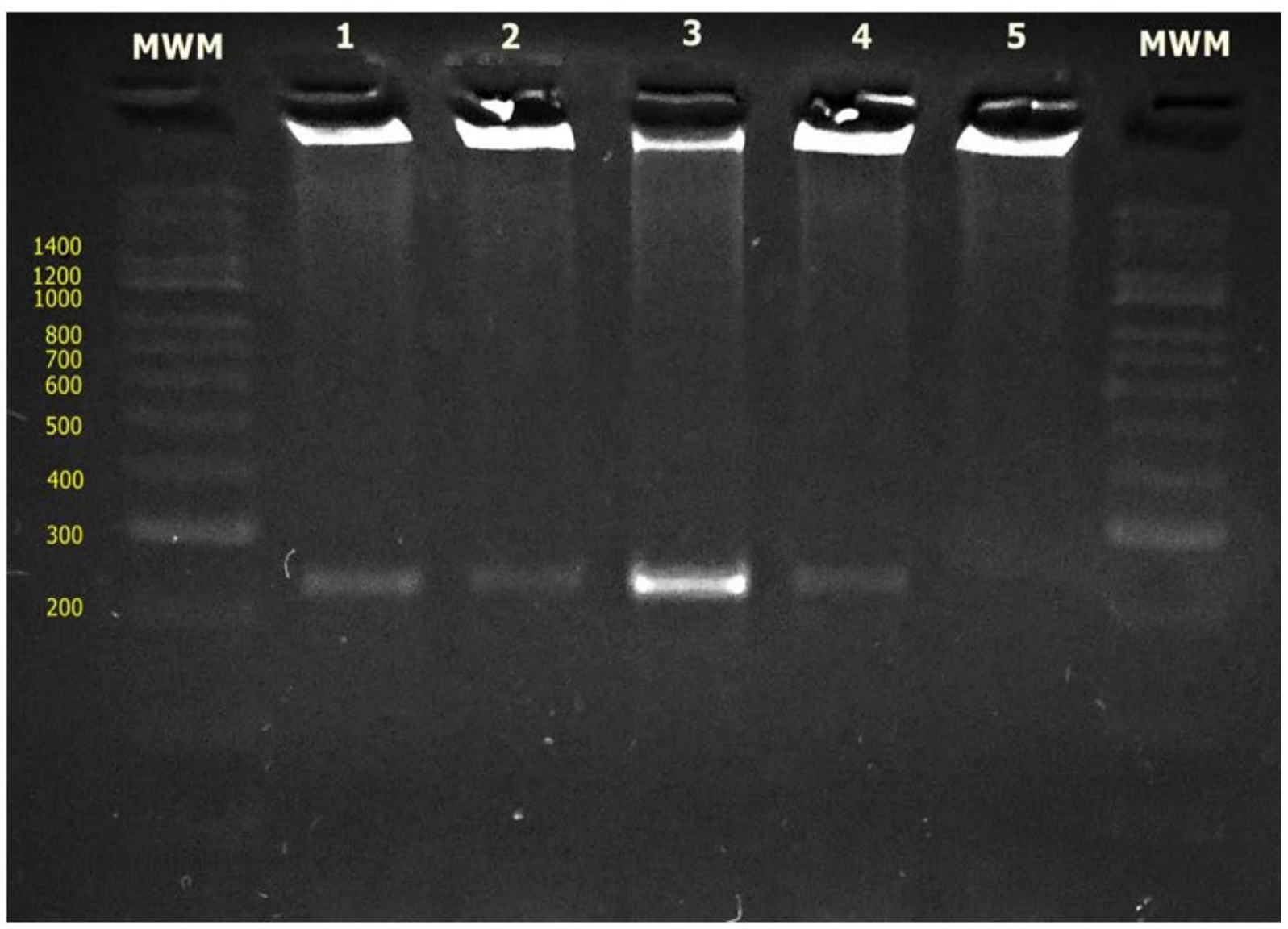


Figure 4. Negative staining electron microscopic examination of the MDBK cell culture. The sample was stained with $2 \%$ phosphotungstic acid. The bars represent $100 \mathrm{~nm}$. At a primary magnification of 30,000x. The capsid of virion (CV) appears to have a hexagonal outline (icosahedral morphology) and is surrounded by a limiting glycoprotein-containing lipid envelope (VE). The average of the measurements was $92 \mathrm{~nm}$ for the virion and $196 \mathrm{~nm}$ for the complete virus with envelope.
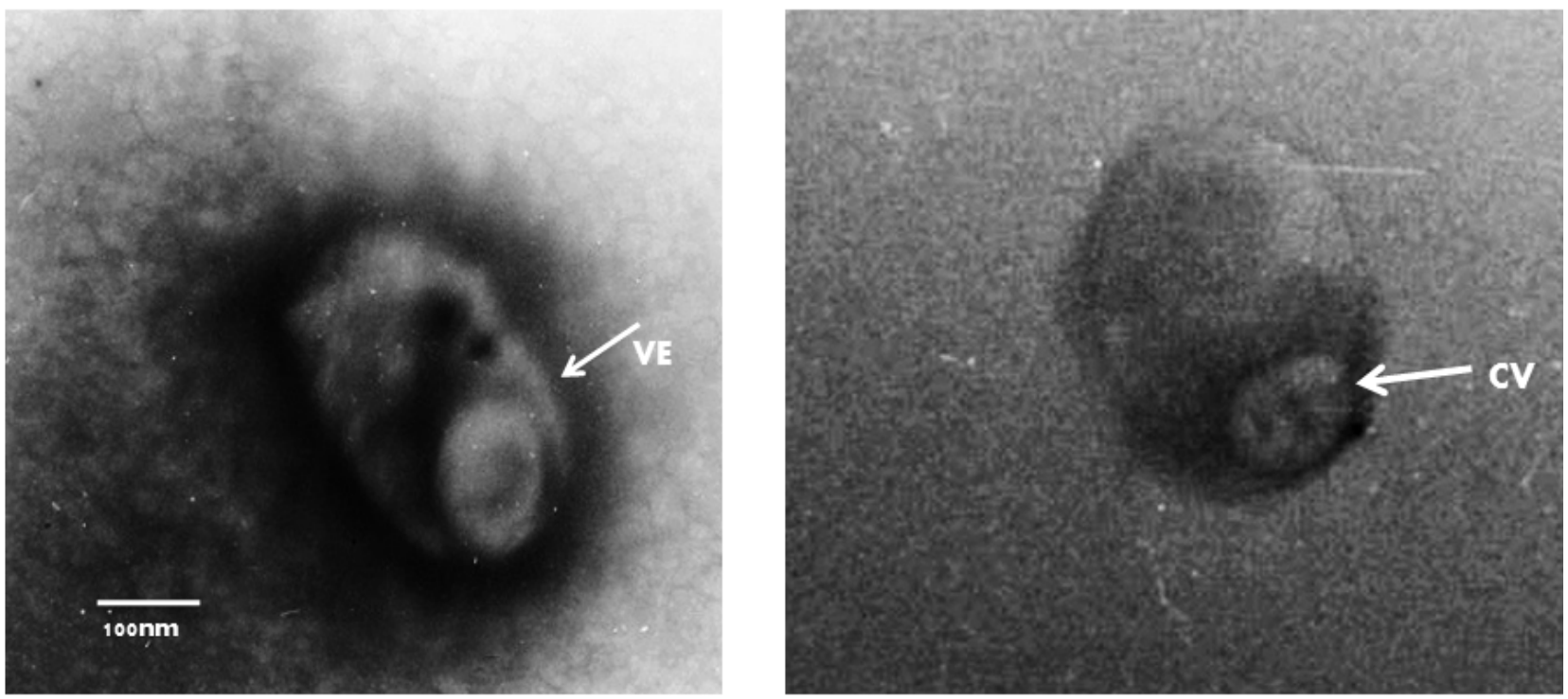

cannot be identified from a vertebrate species. The biology of these viruses is complex, and there has been some suggestion that they form, in essence, a 'viral normal flora' in their hosts (Tarlinton and Dunham 2011).

The positive results of viral isolation in the MDBK cells, the cytopathic and cytolytic effects in the MDBK cells observed at 48 hours, and the positive immunofluorescence, electron microscopic and PCR results of the viral isolates suggest the presence of an alphaherpesvirus (Davison 2010). This is the first report of the identification of the presence of a herpesvirus in free-ranging bottlenose dolphins in Mexico. Although this virus is not associated with any clinical disease, more intense studies must be performed, mainly on stranded cetaceans, to correlate the presence of the virus and the pathological findings. This conclusion is based on the examination of a relatively small number of cases, and further studies are recommended to determine the pathogenic potential of this herpesvirus

\section{Acknowledgments}

The authors Valdivia-Lara and Ortuño de la O were Fellows on the PAPIIT Project IT-224311, which was funded by the General Staff Academic Affairs Support Program (DGAPA-UNAM) Research Projects PAPIITIT224311(2011-2013). Unidad de Investigación Multidisciplinaria, Facultad de Estudios Superiores Cuautitlán, Universidad Nacional Autónoma de México. The sampling was funded by the PEMEX Exploration and Production (PEP), Branch of Industrial Safety and Environmental Protection through its Management Industrial Safety and Environmental Protection Marine Regions located in Ciudad del Carmen, Campeche, México. Special acknowledgement is due to fishermen M. Reyes, M. Cobá, J. Campos, R. Quintal, Carlos Camarena, A. Murillo, S. García and Isla Aguada for their help during the capture process. We also thank Dolphinaris for their support, especially L. Ibarra and A. Casarrubias. This project was conducted under the aegis of research permit no. SGPA/DGVS09924/10 issued by the Dirección General de Vida Silvestre -SEMARNAT. 


\section{Resumen}

Introducción: Se han asociado la presencia de alfaherpesvirus con la mortalidad de varias especies de cetartiodácilos. El objetivo de éste trabajo es aislar microorganismos de toninas silvestres tomando muestras de ejemplares de esta especie en la laguna de Términos, Campeche, México.

Material y métodos: Se capturaron ocho toninas para tomar muestras biológicas como sangre, copro, exudados respiratorio, genital (vaginal o prepucial) y piel para posteriormente ser liberados. De los exudados se estudió la citología y se inocularon cultivos usando células de riñón de bovino (MDCK) y porcino (PK15). Después de observar la citopatología los productos aislados se replicaron en los mismos cultivos celulares al menos tres veces.

Resultados: Tres de los aislamientos presentaron efectos citolíticos entre 48 y $72 \mathrm{hr}$. Para la identificación viral se aplicó un PCR anidado enfocando a la región conservada del herpesvirus obteniendo una amplificación de una región de 240 pares de bases, de manera paralela se identificaron las células utilizando microscopio electrónico de barrido e inmunofluorescencia para las cepas MDBK revelando con gran fluorescencia la presencia de partículas encapsuladas de herpesvirus en los cultivos celulares infectados.

Discusión y conclusiones: Las toninas de las cuales se aislaron los herpesvirus se consideraron clínicamente sanas al momento de su captura y muestreo considerándose portadores o reservorios de éste virus.

Palabras clave: Campeche, herpesvirus, laguna de Términos, México toninas.

\section{References}

Blanchard, T. W., N. T. Santiago, T. P. Lipscomb, L. Richard, R. L. Garber, W. E. Mcfee, and S. Knowles. 2001. Two Novel Alphaherpesviruses Associated With Fatal Disseminated Infections In Atlantic Bottlenose Dolphins. Journal of Wildlife Diseases 37:297-305.

Bossart, G. D. 2007. Emerging Diseases in Marine Mammals: from Dolphins to Manatees. Microbe 2:544-549.

Byron, E. M., M. G. M. Georges, T. K. Verjans, G. V. Amerongen, and A. D. M. E. Osterhaus. 2007. In vitro and in vivo replication of seal gammaherpesviruses in cells of multiple species. Microbes and Infection 9:40-46.

Changming, B., W. Chongming, X., H. S. Junyang, Z. Shual, and H. Jie. 2015. Emerging and endemic types of Ostreid herpesvirus 1 were detected in bivalves in China. Journal of Invertebrate Pathology 124:98-106

Curry, A., H. Appleto, and B. Dowsett. 2006. Application of transmission electron microscopy to the clinical study of viral and bacterial infections: Present and future 37:91-106.

Davison, A. J. 2010. Herpesvirus systematics. Veterinary Microbiology 143:52-69.

Goldstein, T., J. A. K., Mazet, F. M. D. Gulland, T. Rowles, J. T. Harvey, S. G. Allen, D. P. King, B. N. Aldridge, AND J. L. Stott. 2004. The transmission of phocine herpesvirus-1 in rehabilitating and free-ranging Pacific harbor seals (Phoca vitulina) in California. Veterinary Microbiology 103: 131-141.

Heather, T. D., H. N. Hendrik, and D. J. Eric. 2011. Phylogenetic analysis of marine mammal herpesviruses. Veterinary Microbiology 149:23-29.

Herbert, W. V, E. J. Wherry, And R. Ahmed. 2009. Redefining Chronic Viral Infections. Cell 138:30-50.

Maness, H. T. D., H. H. Nollens, E. D. Jensen, T. Goldstein, S. LaMere, A. Childress, J. Sykes, J. St. Leger, G. Lacave, F. E. Latson, and J. F. X. Wellehan. 2011. Phylogenetic analysis of marine mammal herpesviruses. Veterinary Microbiology 149:23-29.

Martineau, D., A. Lagace, P. Bèland, R. Higgens, D. Armstrong, and L. R. Shugart. 1988. Pathology of stranded beluga whales (Delphinapterus leucas) from the St. Lawrence Estuary, Québec. Canadian Journal of Comparative Pathology 98:287-311.

Patela, J. R., J. G. M. Heldensb, T. Bakonyic, And M. Rusvaic. 2012. Important mammalian veterinary viral immunodiseases and their control. Review Vaccine 30:1767-1781.

Rehtanz, M, D. B. Gregory, P. A. Fair, J. S. Reif, S. J. Ghim, and A. B. Jenson. 2012. Papillomaviruses and herpesviruses: Who is who in genital tumor development of free-ranging Atlantic bottlenose dolphins (Tursiops truncatus). Veterinary Microbiology 160:297-304. 
Smolarek, B. K. A., C. A. Manire, R. Y. Ewing, J. T. Salikı, F. I. Townsend, B. Ehlers, and C. H. Romero. 2006. Identification of novel alpha- and gamma herpesviruses from cutaneous and mucosal lesions of dolphins and whales. Journal of Virological Methods 136:261-266.

Soto, S., B. González, K. Willoughby, M. Maley, A. Olvera, S. Kennedy, A. Marco and M. Domingo. 2011. Systemic Herpesvirus and Morbillivirus Co-Infection in a Striped Dolphin (Stenella coeruleoalba). Journal Comparative Pathology 15:269-273.

Tarlinton, R. E., And S. P. Dunham. 2011. Pushing the envelope: Advances in molecular techniques for the detection of novel viruses, Guest Editorial. The Veterinary Journal 190:185-186.

Van Elk, C., W. G. Marco, A. A. Van De Bildt, W. de Jong, D. M. E. Albert, C. Osterhaus, and T. Kuiken. 2009. Genital Herpesvirus in Bottlenose Dolphins (Tursiops truncatus): Cultivation, Epidemiology, and Associated Pathology. Journal of Wildlife Diseases 45:895-906.

Varela, R. A., K. Schmidt, J. D. Goldstein, and G. D. Bossart. 2007. Evaluation of Cetacean and Sirenian Cytologic Samples. Veterynary Clinic Exotic Animals 10:79-130.

Summited: Febreary 8, 2015

Review: April 21, 2015

Accepted: April 29, 2015

Associated editor: Juan Pablo Gallo 
HERPESVIRUS IN TURSIOPS TRUNCATUS

504 THERYA Vol.6(2):495-504 